\title{
Prediction of Karnal Bunt of Wheat Based Upon Weather Variables Prevalence in Northern India
}

\author{
Ravika $^{1 *}$, A.K. Chhabra ${ }^{1}$ and Rajender Singh ${ }^{2}$ \\ ${ }^{1}$ Department of Genetics \& Plant Breeding, CCS Haryana Agricultural University, \\ Hisar-125004, Haryana, India \\ ${ }^{2}$ Department of Plant Pathology, CCS Haryana Agricultural University, Hisar-125004, \\ Haryana, India \\ *Corresponding author
}

\begin{abstract}
A B S T R A C T
Field experiment was conducted to study the role different weather variables on infection of Karnal bunt (KB) disease in Wheat. For the study eighty four recombinant inbred lines

Keywords

Wheat, Karnal

Bunt, Weather and rainfall

Article Info

Accepted:

28 February 2018

Available Online:

10 March 2018

(RILs) of wheat cross, Aldan (resistant) and WH 542 (susceptible) were grown in randomized block design with three replications during season of year 2011-2012 and 20122013. The screening of material was made under artificial conditions in field areas. Inoculum was prepared from 10-12 days old active culture of $N$. indica. Five spikes of each entry were inoculated with $2 \mathrm{ml}$ of inoculum using hypodermic syringe. Disease expression showed during both the years. After harvest, bunted grains were assessed for percent incidence (PI) and coefficient of incidence (CI). Humid Thermal Index (HTI) calculated was ranged from 1.9-5.4 during 2011-12 from November 2011 to April 2012 with average 3.8 for the season. Whereas, during year 2012-13, range of HTI was 2.1-5.2 with seasonal average 3.6. The data indicated that among various meteorological factors, rainfall has shown major effect on the infection of $\mathrm{KB}$ in wheat during both the years with very high $\mathrm{R}^{2}$ value 1.00 . Study revealed that compared to other weather variables; rainfall played major role for establishment of infection at boot leaf stage of the crop.
\end{abstract}

\section{Introduction}

Wheat is one of the most widely grown crops in the world and has unique place among cereals. India is the second largest producer of wheat after China. Most frequently occurring diseases of wheat are rusts (stem, leaf and stripe), loose smut, flag smut, Karnal bunt, hill bunt, foliar blight and powdery mildew (Joshi, 1988). Among these, Karnal bunt is one that forced strict laws under the Sanitary and
Phytosanitory (SPS) agreement (Singh, 2005). The pathogen (Neovossia indica) is seed, soil and air borne in nature infect the plant at boot leaf stage first and then fungal hyphae penetrate the individual floret; and proceed along the ventral crease of kernel. Dark masses of fungal teliospores replace kernel by turning them into powder and give fishy smell caused by the production of trimethylamine (Joshi et al., 1980). The disease finally manifests through formation of teliospores in 
the middle layers of the pericarp. To protect Indian wheat from the losses incurred from export quarantine, in addition to genetic sources of resistance management practices to minimize the incidence are to be needed by researchers to improve local varieties. Various weather variables plays major role in inciting and progress of the disease. Due to monocyclic nature of the disease, very limited information are available on the prediction of Karnal bunt of wheat under field conditions. Therefore, the prediction model if developed can significantly help to apply control measures on time to minimize the incidence and losses by Karnal bunt. The present study was conducted to study the role of weather variables during the wheat growth stages that promoted the incidence of Karnal bunt.

\section{Materials and Methods}

\section{Plant material}

A total of 84 recombinant inbred lines (RILs) of wheat cross, Aldan (resistant) / WH 542 (susceptible) were grown in the crop seasons of 2011-2012 and 2012-2013 at research area of Genetics and Plant Breeding, CCS HAU, Hisar.

\section{Pathogen isolation}

Karnal bunt pathogen Neovossia indica was isolated from the bunted/infected grains and sub cultured on potato dextrose agar (PDA) slants. Pure culture of the pathogen was maintained and stored at $4^{\circ} \mathrm{c}$ for inoculation purpose.

\section{Field inoculation}

The screening of RILs along with their parents Aldan and WH 542 for resistance to Karnal bunt ( $N$. indica) was performed by artificial inoculating the pathogen in the plants. Pathogen inoculum was prepared from 10-12 days old active culture of $N$. indica. The sporidial mass was harvested with the help of inoculating loop in sterilized water and homogenized in vortex mixer for 2-3 minutes. This homogenized mixture was filtered through a muslin cloth and was diluted to the extent that each $\mathrm{ml}$ of inoculum carried approximately 10,000 secondary sporidia. Inoculations of wheat plants were done at boot leaf stage when awns were just emerging during the evening hours. Five to six spikes of each entry were inoculated with $2 \mathrm{ml}$ of inoculum using hypodermic syringe (Aujla et al., 1989) and inoculated spikes were tagged and the relative humidity was maintained between $65-100 \%$. At maturity, wheat grains were harvested from field during both the years and after assessment bunted grains graded based on the visual examination. Wheat kernels which were suspected to be infected with $\mathrm{KB}$ were examined under the microscope to confirm the presence of secondary sporidia of $N$. indica. The grain samples were categorized on the basis of presence and absence of pathogen as the disease is zero tolerance quarantine.

\section{Weather data collection}

Various weather variables viz. maximum temperature $\left(\mathrm{T}_{\max }\right)$, minimum temperature $\left(\mathrm{T}_{\mathrm{min}}\right)$, morning relative humidity $\left(\mathrm{RH}_{\mathrm{m}}\right)$, evening relative humidity $\left(\mathrm{RH}_{\mathrm{m}}\right)$ and rainfall (RF) were included during the wheat growing period i.e. from November to May months of years 2011-12 and 2012-13. Data for the weather variables was obtained from meteorological observatory at CCS Haryana Agricultural University, Hisar.

\section{Humid thermal index model evaluation}

Though the diseases does not show secondary spread therefore the visual progress of diseases can not be possible to study. For the estimation of karnal bunt $(\mathrm{KB})$ of wheat, the 
humid thermal index (HTI) was calculated as per the formula suggested by Jhorar et al., (1992). The formula was as follows:

\section{$\mathrm{HTI}=\mathrm{ERH} / \mathrm{TMX}$}

Where, ERH = is the mean relative humidity at 15:00 hours and TMX is the mean daily maximum temperature over the period covering wheat development stages from heading to anthesis. Whereas, Nagarajan (1991) suggested the prediction model based on the rainfall and rainy days for the particular period during the wheat growth. Therefore, the weather variable information can be used to estimate the diseases incidence in the season. In the present study, weather parameters/variables like maximum temperature and relative humidity at 15:00 hrs, amount and frequency of rainfall and HTI at Hisar were considered for regression analysis for their role in $\mathrm{KB}$ prediction.

Based on previous studies (Smilanick et al., 1985, Singh, 1994; Zhang et al., 2005), the conditions for the germination of teliospores of $N$. indica were observed at temperature 5$35^{\circ} \mathrm{C}$ and $60-95 \%$ relative humidity. Therefore, the above model could be modified and expressed with the formulas:

$\mathrm{HTI}=\mathrm{ERH} / \mathrm{TMX}(5 \leq \mathrm{T} \leq 35$ and $60 \% \leq \mathrm{RH}$ $\leq 95 \%$ )

$\mathrm{HTI}=0(\mathrm{~T}<5$ or $\mathrm{T}>35$ or $\mathrm{RH}<60 \%$ or $\mathrm{RH}$ $>95 \%)$

Where, $\mathrm{T}$ is mean temperature $\left({ }^{\circ} \mathrm{C}\right)$ and $\mathrm{RH}$ is the mean relative humidity $(\%)$ during heading and anthesis.

Data was analyzed and regression equation was developed for two years separately. The HTI for KB was categorized and the risk of disease was estimated. Based on HTI score for particular period disease risk was estimated.

\section{Results and Discussion}

There was a wide variation among RILs for disease expression during the year 2011-12 and 2012-13. Out of 84 RILs, 30 were categorized to show symptoms of karnal bunt during 12 whereas, during 13 only 22 RILs showed susceptible reaction to karnal bunt (Table 1). Eleven RILs were highly resistant with $0 \%$ infection. During both the year forty two RILs showed resistant reaction $(0.1-5 \%)$ during first year 2011-12 whereas for second year 2012-13 forty six RILs were observed under this category. Nineteen RILs were moderately susceptible (5.1-10\%) during first year and twenty RILs during second year were under the same category. Eleven RILs showed susceptible reaction (10.1-20\%) during first year and seven RILs were included in this category during year 2013. There was only one RIL with infection above $20 \%$ there in the year 2012, whereas, in second year no RIL showed infection more than 20\% (Figure 1). Data was analysed, analysis of variance and the regression equation was calculated to observe the role of environmental factors on the incidence of KB. The regression equation calculated was as follows:

$\mathrm{Y}=21.092+0.766 \mathrm{X}_{1}$

Where, $\mathrm{Y}=$ prediction value of $\mathrm{KB}$ incidence and $\mathrm{X}_{1}=$ Rainfall

The meteorological data for 2011-12 and 2012-13 obtained was used to analyse the role of various weather variables in the development of KB (Table 2). The data indicated that among various meteorological factors, only rainfall has major effect on the infection of $\mathrm{KB}$ in wheat during both the years and showed very high $\mathrm{R}^{2}$ value 1.00 . Which indicated $100 \%$ role of rainfall in the incidence of $\mathrm{KB}$ of wheat during the boot leaf stage of crop. The prediction equation calculated can be used to predict the incidence 
of $\mathrm{KB}$ based on the rainfall occurred during the season.

Humid Thermal Index observed was ranged from 1.9-5.4 for 2011-12 from November 2011 to May 2012 with average HTI of 3.8 for the season. Whereas, during 2012-13, range of HTI was 2.1-5.2 with seasonal average 3.6.
High HTI value indicated more humid condition and lower HTI value indicated dry period during the season (Table 3). Therefore, the data presented here proposed that HTI value below 2.0 observed some dry spell or hot weather; whereas, HTI more than 3.0 indicated cold or wet environment for incidence and development of Karnal bunt.

Table.1 Range of PI (\%) and CI (\%) in Susceptible RILs during year 2011-12 and 2012-13

\begin{tabular}{|c|c|c|c|c|c|c|}
\hline S. N. & RIL & PI (\%) & CI (\%) & RIL & PI (\%) & CI (\%) \\
\hline 1 & 6 & 28.44 & 18.91 & 6 & 24.57 & 17.54 \\
\hline 2 & 12 & 21.83 & 15.98 & 18 & 30.85 & 20.4 \\
\hline 3 & 17 & 21.27 & 14.21 & 21 & 29.58 & 23.04 \\
\hline 4 & 18 & 37.56 & 23.18 & 26 & 24.47 & 16.91 \\
\hline 5 & 19 & 21.73 & 15.27 & 34 & 23.45 & 15.06 \\
\hline 6 & 21 & 33.38 & 25.03 & 37 & 23.74 & 15.7 \\
\hline 7 & 24 & 22.94 & 15.74 & 40 & 22.99 & 15.83 \\
\hline 8 & 26 & 28.33 & 18.73 & 41 & 28.03 & 18.0 \\
\hline 9 & 28 & 22.91 & 16.07 & 45 & 22.5 & 13.21 \\
\hline 10 & 34 & 27.54 & 16.78 & 46 & 41.08 & 24.68 \\
\hline 11 & 37 & 27.47 & 18.0 & 50 & 20.53 & 14.49 \\
\hline 12 & 40 & 27.02 & 17.52 & 55 & 22.15 & 15.19 \\
\hline 13 & 41 & 31.46 & 19.58 & 56 & 24.51 & 21.57 \\
\hline 14 & 45 & 26.53 & 15.92 & 60 & 28.88 & 18.1 \\
\hline 15 & 46 & 46.39 & 27.47 & 61 & 24.86 & 15.57 \\
\hline 16 & 47 & 23.12 & 15.53 & 67 & 24.59 & 18.19 \\
\hline 17 & 50 & 25.41 & 17.21 & 71 & 29.09 & 18.56 \\
\hline 18 & 51 & 20.88 & 15.08 & 73 & 21.08 & 13.21 \\
\hline 19 & 54 & 22.36 & 13.17 & 74 & 30.12 & 18.95 \\
\hline 20 & 55 & 26.95 & 16.51 & 77 & 24.68 & 16.4 \\
\hline 21 & 56 & 29.82 & 23.47 & 81 & 25.12 & 14.43 \\
\hline 22 & 60 & 32.2 & 19.86 & WH 542 & 31.58 & 22.3 \\
\hline 23 & 61 & 29.39 & 17.92 & - & - & - \\
\hline 24 & 67 & 29.21 & 19.39 & - & - & - \\
\hline 25 & 71 & 32.56 & 19.65 & - & - & - \\
\hline 26 & 73 & 26.32 & 14.58 & - & - & - \\
\hline 27 & 74 & 33.23 & 20.53 & - & - & - \\
\hline 28 & 77 & 28.67 & 18.4 & - & - & - \\
\hline 29 & 81 & 27.68 & 15.85 & - & - & - \\
\hline 30 & WH 542 & 36.58 & 24.81 & - & - & - \\
\hline
\end{tabular}


Table.2 Meteorological data of Temperature, Relative humidity and Rainfall during the year 2011-12 and 2012-13

\begin{tabular}{|c|c|c|c|c|c|c|c|}
\hline Sr. no. & Month & \multicolumn{6}{|c|}{ 2011-12 } \\
\hline & & \multicolumn{2}{|c|}{ Temperature $\left({ }^{\circ} \mathrm{C}\right)$} & \multicolumn{2}{|c|}{ Relative humidity (\%) } & \multirow[t]{2}{*}{ Rainfall (mm) } & \multirow[t]{2}{*}{ HTI } \\
\hline & & Max. & Min. & Morning & Evening & & \\
\hline 1 & November, 2011 & 27.4 & 9.2 & 92.0 & 38.0 & 0.0 & 3.4 \\
\hline 2 & December, 2011 & 20.8 & 6.0 & 93.0 & 58.0 & 5.5 & 4.5 \\
\hline 3 & January, 2012 & 17.6 & 4.2 & 95.0 & 58.0 & 43.0 & 5.4 \\
\hline 4 & February, 2012 & 21.5 & 8.9 & 96.0 & 60.0 & 32.7 & 4.5 \\
\hline 5 & March, 2012 & 28.4 & 12.0 & 92.0 & 47.0 & 31.1 & 3.2 \\
\hline \multirow[t]{3}{*}{6} & April, 2012 & 35.0 & 17.2 & 68.0 & 27.0 & 2.3 & 1.9 \\
\hline & Mean of year & 25.1 & 9.6 & 89.3 & 48.0 & 19.1 & 3.8 \\
\hline & & \multicolumn{6}{|c|}{ 2012-13 } \\
\hline 1 & November, 2012 & 29.2 & 10.3 & 91.0 & 36.0 & 0.0 & 3.1 \\
\hline 2 & December, 2012 & 22.9 & 5.2 & 95.0 & 43.0 & 0.0 & 4.1 \\
\hline 3 & January, 2013 & 18.4 & 4.8 & 96.0 & 51.0 & 0.0 & 5.2 \\
\hline 4 & February, 2013 & 21.1 & 5.3 & 87.0 & 40.0 & 0.0 & 4.1 \\
\hline 5 & March, 2013 & 28.7 & 10.6 & 83.0 & 32.0 & 0.0 & 2.9 \\
\hline \multirow[t]{2}{*}{6} & April, 2013 & 34.2 & 18.0 & 73.0 & 38.0 & 33.3 & 2.1 \\
\hline & Mean of year & 25.8 & 9.0 & 87.5 & 40.0 & 5.6 & 3.6 \\
\hline
\end{tabular}

Fig.1 Histogram showing percentage of infection in RILs during the year 2012 and 2013

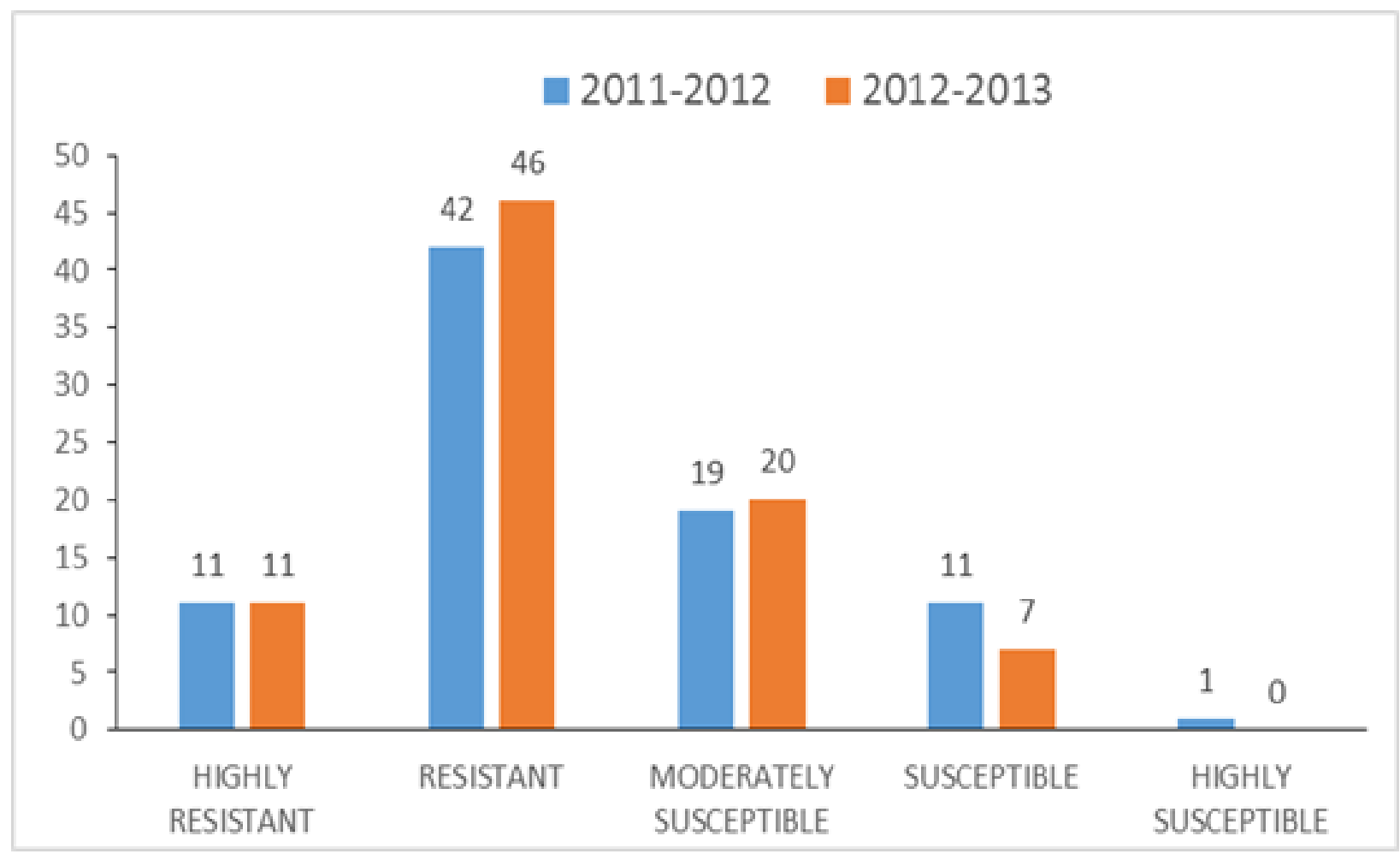


The role of meteorological parameters such as temperature, relative humidity, light, sunshine and precipitation period in the incidence and progression of plant diseases has already been documented by the researchers. A certain range and combination of meteorological parameters for a certain period might be conducive for diseases in plants. The present study revealed the role of various weather or meteorological factor in the incidence and development of Karnal bunt of wheat. The meteorological values from Table 3 showed that average maximum (Tmax) temperature was $25.1{ }^{\circ} \mathrm{C}$ during $2011-12$ and $25.8^{\circ} \mathrm{C}$ during 2012-13. Whereas, $\mathrm{T}_{\min }$ was $9.58^{\circ} \mathrm{C}$ during 2011-12 and $9.0{ }^{\circ} \mathrm{C}$ during 2012-13. Previous studies exhibited that temperature plays important role in the survival of primary sporidia of $N$. indica as they are temperature sensitive (Nagarajan et al., 1997). In the present study morning relative humidity was $89.3 \%$ during 2011-12 and 87.5 \% during 2012-13. The major difference was observed in rainfall during the pathogen survival stage in crop. The evening relative humidity was $48.00 \%$ during 2011-12 and 40.0\% during 2012-13. The average rainfall during 2011-12 was $19.10 \mathrm{~mm}$ as compared to $6.66 \mathrm{~mm}$ rainfall during 2012-13 (Table 3). Role of $\mathrm{RH}$ in addition to temperature in the disease development has been studied very well by the researchers already. Rainfall during the booting and ear emergence stage has been documented as most necessary for the development of sporidia on leaves. Nagarajan et al., (1997) strongly supported the crucial role of rainy days in the severity of karnal bunt and developed the prediction model with $\mathrm{R}^{2}=0.89$. In addition, they also suggested the role of location on the incidence of the disease.

In the present study, the seasonal temperature was remained between $11^{\circ} \mathrm{C}$ to $27.5^{\circ} \mathrm{c}$ during heading and anthesis, which met the requirements for the germination of teliospores of $N$. indica. The HTI model indicated the role of humidity for the secondary spread of the spores that played as the key factor to limits the prevalence of disease. Since, rainfall is closely related with humidity which has been used in many predictive models. Previous study also indicated that, suitable temperature, high relative humidity and cloudy, rainy weather promoted the disease development, whereas, dry conditions, high temperature and sunshine were considered as unfavourable factors (Warham, 1986; Singh, 1994; Fuentes-Davila, 1996; Nagarajan et al., 1997) for the development of Karnal bunt.

It has been observed that for the establishment of infection of Karnal bunt ( $N$. indica) weather variables played a major role especially rainfall that contributed as major factor. The period of rainfall contributed in maintenance of $\mathrm{RH}$ for the fungal infection and multiplication within the plant. Therefore, prediction of incidence of Karnal bunt can be made on the basis of the weather variable and the control measures can be adopted as per the requirements. However, the monocyclic nature of disease limits the exact measurement of diseased plants before maturity.

\section{References}

Fuentes-Davila, G. 1996. Karnal bunt. In: Wilcoxson R.D., Saari E.E. (ds). Bunt and Smut Diseases of Wheat: Concepts and Methods of Disease Management, 26-32. CIMMYT, El Batan, Mexico.

Jhorar, O.P., Mavi, H.S., Sharma, I., Mahi, G.S., Mathauda, S.S., Singh, G. 1992. A biometeorological model for forecasting Karnal bunt disease of wheat. Plant Disease Reporter 7: 204-209.

Joshi, L.M. 1988. Plant pathological problems in India as exemplified by Karnal bunt of wheat. Indian J Mycol. Plant Pathol, 
17: 11-21.

Joshi, L.M., Singh, D.V. and Srivastava, K.D. 1980. Present status of Karnal bunt in India. Indian Phytopathol, 33(1): 147-148.

Nagarajan, S. 1991. Epidemiology of Karnal bunt of wheat incited by Neovossia indica and an attempt to develop a disease prediction system. Technical Report, Wheat Programme, CIMMYT, El Batan, Mexico.

Nagarajan, S., Aujla, S.S., Nanda, G.S., Sharma, I., Goel, L.B., Kumar, J., Singh, D.V. 1997. Karnal bunt (Tilletia indica) of wheat: A review. Review of Plant Pathology, 76: 1207-1214.

Singh, A. 1994. Epidemiology and management of Karnal bunt disease of wheat. Research Bulletin No. 127, Directorate of Experiment Station, G.B. Pant University of Agriculture and Technology, Pantnagar, India.
Singh, D.V. 2005. Karnal bunt of wheat: A Global Perspective. Indian Phytopathol. 58:1-9.

Smilanick, J.L., Hoffmann, J.A., Royer, M.H. 1985. Effect of temperature, $\mathrm{pH}$, light, and desiccation on teliospore germination of Tilletia indica. Phytopathology 75: 1428-1431.

Stansbury, C.D. and Pretorius, Z.A. 2001. Modeling the potential distribution of Karnal bunt of wheat in South Africa. South Afric.J. Plant and Soil, 18: 159168.

Warham, E.J. 1986. Karnal bunt disease of wheat: a literature review. Tropical Pest Management 32: 229-242.

Zhang, G.M., Zhang, Z., Cheng, Y.H., Sun, Z.Q., Wang, Y., Jing, X.Z., Jiang, Z.D., Liu, Y., Yao, Y.J., Qi, P.K. 2005. Establishment of Detecting Platform for Plant Pathogenic Fungi. China Agricultural Press, Beijing, China.

\section{How to cite this article:}

Ravika, A.K. Chhabra and Rajender Singh. 2018. Prediction of Karnal Bunt of Wheat Based Upon Weather Variables Prevalence in Northern India. Int.J.Curr.Microbiol.App.Sci. 7(03): 3639-3645. doi: https://doi.org/10.20546/ijcmas.2018.703.420 